\title{
Normen en waarden: uit het dagboek van een hoofdredacteur
}

\author{
JOHAN OOSTERMAN
}

Op 24 mei 2002 komt de redactie van Literatuur, het in 1983 opgerichte Tijdschrift over Nederlandse letterkunde, samen in Antwerpen voor een vergadering die feestelijk had moeten worden. Maar kort voordien is er bericht gekomen van het Nederlands Literair Produktie en Vertalingenfonds met een negatief oordeel over de koers van het blad. Als er niets verandert, stopt de subsidie over een jaar. Helaas is een blad als Literatuur te afhankelijk van die subsidie om onverschillig te blijven onder dit nieuws. Tijdens de vergadering en meer nog tijdens de terugreis per trein wordt gepraat over de toekomst van het blad. Een van de redacteuren zegt, wanneer we afscheid van elkaar nemen: 'Nou Johan, nog drie nummers en dan is het voorbij.' In de weken nadien oriënteer ik me op vergelijkbare bladen in binnen- en buitenland, praat ik met mensen binnen en buiten de redactie, en schrijf ik uiteindelijk een stuk dat, voorgelegd aan redactie en uitgeverij, het uitgangspunt vormt voor concrete plannen: in de zomer van 2002 besluiten redactie en uitgever van Literatuur dat het blad een andere koers moet varen. De nieuwe opzet, de strakkere productieschema's en de actievere rol van de redactie bij het verwerven van kopij, maken het wenselijk dat er zoiets als een hoofdredacteur komt. Ik neem die taak - van harte en met plezier - op me. In een ijzeren regelmaat hebben we sindsdien gewerkt aan een Magazine over Nederlandse letterkunde dat toegankelijk, stimulerend en onderhoudend moet zijn. Laat anderen maar oordelen of we daarin geslaagd zijn. Her onderstaande 'dagboek' - gestileerd maar niet gefingeerd - beschrijft een periode waarin het goed begon te lopen met het blad in nieuwe opzet. De redacteuren die in die periode bij Literatuur betrokken zijn, zijn Micky Cornelissen, Suus Hopman, Sasja Koetsier, Sabine Kok, Johan Koppenol, Lisa Kuitert, Marja Pruis en ondergetekende. 
$7 \mathrm{MEI} 2003 \mathrm{Na}$ een warm weekeinde is het fris vandaag. Om twee uur's middags redactievergadering, de eerste keer met Marja. Een leuke levendige vergadering, veel nieuwe ideeën. Eindelijk een onderwerp voor nummer 7 van dit jaar: 'Normen \& waarden'. Iedereen spreekt erover sinds Balkenende de discussie heeft aangezwengeld, maar het debat spitst zich wel erg toe op de publieke moraal. In de literatuur gaat het over veel meer: over spelling, over poëtica, over maatschappelijke betrokkenheid, over seksuele taboes. Als we daar nu eens een mooi dossier over maken...

Met het zomernummer - over Wandelen - loopt alles goed: volgende week eerste proef.

19 MEI Eerste proef zomernummer binnen. Ziet er mooi en vrolijk uit. Over de opmaak van het literaire Pieterpad zijn Sabine en ik niet helemaal tevreden. Het is wat statisch. Voor het eerst zijn er wat korte stukken gesneuveld, juist nu we een dubbelnummer hebben. De problemen aan het begin van dit jaar om voldoende kopij binnen te krijgen zijn voorbij. We beginnen lekker te draaien met ons blad, de kopij stroomt binnen, en nog mooi op tijd ook.

20 MEI Met Marja gesproken over taboes, seks en porno in het werk van Franse en Nederlandse schrijfsters. Wie kan daarover een stuk schrijven in ons Normen en waarden-dossier? Misschien Joke Hermsen. Marja kent haar en zal eens informeren.

21 MEI Marketing heeft goed werk gedaan: Arts en auto, met een oplage van vele tienduizenden, wil een stuk van ons overnemen. Ze kiezen voor Johan Koppenols artikel over de rentenierende arts Westerbaen. Johan is net zo verbaasd over die belangstelling als ik: 'Nou, dit moeten we ook weer even allemaal verwerken. Artsen auto... Maar goed.'

Vanochtend: tecensie in de Volkskrant: 'Het oogt aardig, de thema's zijn boeiend, maar de uitwerking is niet meer dan een aanzet.'

26 ME1 Berichtje van Lisa: lovende recensie in de Haagsche Courant! De kritiek begint onze nieuwe opzet te waarderen. Marja laat me weten dat Joke Hermsen een stuk wil schrijven, maar ze vraagt of de deadline naar september ver- 
schoven kan worden. Nee! We moeten streng zijn tegenwoordig, de kopij moet op 25 augustus persklaar bij de uitgever zijn, ik heb voordien een paar dagen nodigen om te redigeren. Ook Hermsen moet zich schikken. Ik bel haar maar even, en ze blijkt bereid zich aan onze voorwaarden te houden.

28 MEI De eerste stukken voor nummer 6 - dossier De student - komen binnen. Ik stuur maar vast een min of meer definitief overzicht van de inhoud naar Sabine en Suus.

5 JUNI De komende weken op vakantie, maar eerst nog wat laatste afspraken met auteurs voor het Normen en waarden-dossier. Een uitvoerige mail naar de redactie zodat ze het drie weken zonder mij kunnen en uitgebreid gebeld met Micky die de komende weken de dagelijkse zaken regelt.

6 JUNI Naar Narbonne, ruim drie weken fietsen in Languedoc en Provence. We zijn de afgelopen week alvast opgewarmd: in het weekeinde was het 26 graden, in Frankrijk nu net zulke temperaturen.

13 JUNI Na een aantal tamelijk warme dagen schiet de temperatuur voor het eerst flink omhoog: 35 graden, en ik kom op het onzalige idee om bij Saint-Guilhem-le-Désert een berg op te willen fietsen.

23 JUNI Aangekomen in Suze-la-rousse, het plaatsje van waaruit we morgen weer terugkeren naar Nederland. Na weer een zinderend hete dag gaan we eten bij een goed restaurant met hooggelegen terras: lekker in de wind, mooi uitzicht, een aangename rust. Plots, tussen hoofd- en voorgerecht, komen tien Harleys de oprijlaan opgereden. Tien Hells Angels uit Tongeren in Belgisch Limburg - zo staat op hun leren jacks - stappen af en komen het terras op. Ze blijken te hebben gereserveerd in het hotel. De leider van de groep haalt de sleutels van de gereserveerde kamers en de tien gaan het hotel binnen. De rust keert terug. Even gingen mijn gedachten naar het dossier over Normen en waarden. Bijna thuis.

27 JUNI Gisteren thuisgekomen. Vanochtend eerstejaars tentamen afgenomen, vanmiddag redactievergadering. Er zijn geen rampen gebeurd, de ko- 
pij voor nummer 6 is binnen, en waarschijnlijk weer een klein overschot aan stukken. Zo hoort het: een goeddraaiende redactie. Het onderzoekje onder studenten - wat lezen studenten? - heeft aardige resultaten opgeleverd en Sasja heeft inmiddels een eerste opzet voor het artikel. We kijken er de komende tijd nog naar. Na de vergadering nemen we op een terras afscheid van Micky, die ons als redactiesecretaris die lastige eerste fase heeft doorgeloodst. Cadeautjes, kussen, veel hartelijks. En na vanmiddag is mijn onmisbare velletje met de jaarplanning helemaal gevlekt, niet door geplengde tranen maar omdat een licht regenbuitje de inkt deed doorlopen. Na vandaag gaat een groot deel van de redactie op vakantie, maar met de komende nummers loopt het goed. Geen zorgen.

I JULI Het zometnummer is uit, met het dossier Wandelen én met het Boekhandelsonderzoek. Vooral dat laatste trekt - na een persbericht - al dagen veel aandacht in de media en bij de beoordeelde boekhandelaren. Sommigen zijn woedend, voelen zich door ons ten onrechte door het slijk gehaald.

9 JULI Gisteren flink gesnoeid in de kopij voor nummer 6. Bijna alle auteurs hebben meer geschreven dan gevraagd. Eén antwoordde na het lezen van zijn ingekorte stuk: 'Je kaasschaafmethode is erg instructief voor m'n eigen, al te wollige uitdrukkingen'. Waarom is het makkelijker andermans teksten in te korten dan die van jezelf?

16 JULi Nummer 6 is klaar en kan naar de vormgever, alleen mijn tekstjes - wat koppen en bijschriften - moeten nog af. Terecht spoort Suus me aan haast te maken: 'Vergeet je alsjeblieft niet dat ik Bert morgen om uiterlijk 11 uur een gebrande $\mathrm{cd}$ met alles compleet moet overhandigen? Dus als ik alles om 10 uur niet heb wordt ik een beetje zenuwachtig'. Ik vergeet wel eens dat mijn deadline-gedrag anderen flink op de zenuwen kan werken.

21 JULI Om 10 uur gesprek met Saskia de Vries van de AUP, die tevreden is over de nieuwe koers maat hier en daat de publieksgerichtheid wil aanscherpen. Goed om nog eens over na te denken. 
30 JU LI Drukproeven van nummer 6 met Sabine doorgenomen. Ondertussen begin ik me knap zorgen te maken over nummer 7 - Normen en waarden - want al die ijverig schrijvende auteurs blijken ineens een writer's block te hebben: er is nog bijna niets binnen. Iedereen klaagt dat het warme weer hem of haar van het werken afhoudt. Tja. Wat moet ik daar nu op zeggen. Besluit in elk geval zelf maar een stuk te schrijven over de vertaling van Tasso's Gerusalemme liberata en haar talrijke Nederlandse voorgangers.

8 AUGUSTUS Eindelijk het ingewikkelde proefschrift te pakken over de ziekelijk schuwe schrijver Maurice Blanchot. Misschien kan Liesbeth Eugelink er nog een stuk over schrijven voor het Normen en waarden-dossier. In ieder geval heeft ze beloofd haar best te doen. Zulke auteurs zijn onwaardeerlijk! De jaarplanning voor volgend jaar is binnen: op 24 november verschijnt het laatste nummer van 2004.

13 AUgustus Mijn Tasso-stuk is af. Door naar de redactie voor een rondje vrij schieten.

18 AUGUSTUS Krabbel nog maar weer eens een lijstje met toegezegde stukken en een schatting van hun omvang, en tot mijn schrik - wat ik eigenlijk al wist - te weinig stukken en allemaal iets korter dan afgesproken. Zou dat de tol van deze hete zomer zijn. Zelfs Lisa, die nooit te laat is, redt het niet. En dan maar hopen dat de beloofde stukken van Liesbeth E. en Joke H. binnenkomen. Ineens ben ik niet zo zeker dat het deze keer lukt.

21 AUGUSTUS Berichtje van Marja over een kwestie die me al heel wat koppijn heeft bezorgd: de reactie van boekhandel $G$ te $H$ op de beoordeling van hun zaak in ons onderzoek. Ze waren eerst boos, toen woedend. En de uitgever, zenuwachtig, wist zich er niet goed raad mee. Misschien nog zorgvuldiger zijn met zulke onderzoekjes, raadt Marja aan. Ik denk ze gelijk heeft, helaas. Stuk van Pieter van Os binnen. Langer dan afgesproken. Gelukkig!

25 AUgustus Lunch met Liesbeth E. - die een mooi stuk over Blanchot en Coetzee heeft geschreven - bij de Lux. Ze vertelt me over haar ideeën voor 
een dossier over onzichtbaarheid. Heerlijk in de schaduw en de wind. Morgen moet de kopij naar Bert, maar veel stukken zijn nog niet binnen.

28 AUGUSTUS Nummer 6 verschijnt! En alweer volop publiciteit, vooral over ons onderzoekje onder studenten. Of je nu concludeert dat ze veel lezen, of juist weinig, de pers vindt het prachtig. Kom met een onderzoekje of een toptien, en de media nemen het over. Een truc die altijd werkt. We gaan er vast vaker gebruik van maken.

5 SEPTEMBER Volgens planning de eerste proef van nummer 7 . Heel veel wit - zou gepast zijn voor het nummer over onzichtbaarheid, dat we volgend jaar willen maken - maar staat nu erg treurig.

8 SEPTEMBER Domme pech: Filosofie Magazine van deze maand heeft precies onze jeugdige Feyenoordfan op het omslag. Dat kunnen wij dus niet meer doen. Nou ja, niet iedereen was gelukkig met deze keuze. Het lot dwingt ons tot een ander plaatje.

IO SEPTEMBER Eindelijk maar toch, het stuk van Joke $H$., die door extreme hitte in haar vakantiehuis in Frankrijk niet tot schrijven was gekomen. Ook nu zijn we niet helemaal tevreden - zijzelf ook niet, schrijft ze. Maar tijd om te herzien heeft ze niet. Marja biedt aan het stuk te redigeren.

Aangetekende brief van boekhandel $\mathrm{G}$ te $\mathrm{H}$ bij de post. De dames boekhandelaren zijn niet tevreden met de brief die ik ze namens de redactie heb geschreven. Ze dreigen met een rechtzaak. Het wordt almaar leuker om hoofdredacteur te zijn.

12 SEPTEMBER Marja is gereed met het stuk van Joke $\mathrm{H}$. Ik heb het redactioneel af, deze keer over het nut van Nederlands studeren.

19 SEPTEMBER Sabine aan de telefoon. Alle pogingen om een goede plaat voor het omslag te vinden zijn mislukt. Die prachtige Mozes uit het paleis op de Dam is binnengekomen, maar de kwaliteit is te slecht. Wat nu? Ze vertrekt voor een paar dagen naar de Ardennen, heeft geen tijd meer. Ik beloof 
het te regelen. Tegen beter weten in. Waar moet ik nu nog iets vandaan halen? Het is vrijdagmiddag. Bel met het kunsthistorische documentatiecentrum en spreek af voor maandagochtend.

22 SEPTEMBER Meteen om negen uur op zoek naar een geschikte afbeelding. Blijkt moeilijker dan gedacht, maar uiteindelijk komt er een mooie Deense Mozes uit de dertiende eeuw uit de bus. Plaatje gescand en per koerier naar Bussum zodat Bert Haagsman vandaag nog de opmaak kan afronden.

24 SEPTEMBER Jaap Wagenaar stuurt me de tweede proef toe, waarin nu niks meer veranderd kan worden omdat het nummer gisteren al naar de drukker is gegaan. Alle pagina's zijn gevuld, het is een nummer zoals alle andere geworden. Wie deze aflevering straks in handen krijgt ziet niets meer van de warme en hectische zomer van 2003.

7 OKTOBER 2003 Nummer 7 verschijnt - Normen en waarden - met Mozes op het omslag, en met een nieuwsbericht naar aanleiding van het boekhandelsonderzoek. Boekhandel $\mathrm{G}$ te $\mathrm{H}$ kan tevreden zijn: hun brieven staan integraal op de website. En ik ben tevreden met dit nieuwe nummer. Misschien niet ons beste, maar ook zeker geen slecht nummer. En het blijkt verrassend actueel: twee artikelen in het dossier gaan uitvoerig in op Elisabeth Costello, de laatste roman van Coetzee; op 2 oktober werd bekend dat hij de Nobelprijs voor literatuur krijgt. We proberen met ons prachtblad actueel te zijn, soms heb je daar het stomme toeval voor nodig.

Literatuur kent over 2003 en 2004 een toenemend aantal lezers en krijgt steeds vaker positieve besprekingen in de pers. Maar op 2 juli 2004, tijdens een vergadering van de volledige redactie met Anniek Meinders, de verantwoordelijke uitgever, krijgen we te horen dat het slecht gaat: er is een daling in het aantal abonnees en de uitgeverij zal in het najaar besluiten of doorgaan wel verantwoord is. Mijn ongeloof blijkt later terecht: de cijfers zijn verkeerd geinterpreteerd. Het blad groeit, zij het langzaam, en heeft door recente wervingsacties enkele honderden proefabonnees. Eind september 2004 besluit AUP definitief te stoppen met de uitgave van het tijdschrift. In een brief van 
28 september maakt Anniek Meinders dit bekend. Ze memoreert dat er door de redactie met veel inzet een blad is neergezet om trots op zijn.

Haar oordeel wordt bijna een jaar later bevestigd in het Rapport Literaire Tijdschriften 2004, dat mij op 25 augustus 2005 is toegezonden. De beoordelingscommissie van het Nederlands Literair Productie- en vertalingenfonds toont zich bewust van het feit dat haar beoordeling geen relevantie meer heeft wat betreft de subsidie. Toch geeft ze haar beoordeling: 'Jaargang 2004 maakt glashelder dat Literatuur geen literair tijdschrift meer is, maar een (journalistiek) magazine dat wetenswaardigheden wil geven op het terrein van de literatuur en het literatuurbedrijf. De redactie is erin geslaagd in de nieuwe formule te groeien, en van Literatuur het publiekstijdschrift te maken dat haar bij aanvang voor ogen stond.'

In de maanden die volgen slaagt de redactie er niet in een uitgever te vinden die het blad wil voorzetten. Begin december, een paar weken later dan voorzien, verschijnt aflevering 8 van jaargang 21 . Het dossier is gewijd aan 'Onzichtbaarheid'. Het doek lijkt definitief gevallen - de beoordelingscommissie van het Productiefonds heeft het in haar rapport over 'onverhoeds opgeheven' - en de samenwerking met AUP eindigt in mineur. Ik heb slechte herinneringen aan die periode vootal omdat sommige betrokkenen wat mij betreft onnodig de vraag aan de orde stellen wie schuld heeft aan het gebeurde.

Maar er komt een vervolg. Al aan het einde van 2004 stuurt Sander Pleij, adjunct-hoofdredacteur van De Groene Amsterdammer, een kort bericht: 'wij zijn ook een uitgever!' Er volgen gesprekken en op 23 januari volgt een voorlopige conclusie: 'Samenvattend kan ik je dus geen toezegging doen, maar wel de intentie uitspreken dat we graag de mogelijkheden onderzoeken. Dit project zou een welkome aanvulling voor ons betekenen.' In de zomer van 2005 is duidelijk dat De Groene Amsterdammer als bijlage bij het weekblad enkele keren per jaar een magazine gaat uitgeven over Nederlandse letterkunde, gemaakt door redacteuren van Literatuur én De Groene. Op 9 november 2005 verschijnt het eerste nummer.

. JOHAN OOSTERMAN is universitair docent Nederlandse letterkunde aan de Radboud Universiteit Nijmegen 